\title{
Metastatic Renal Cell Carcinoma: Sunitinib as First-Line Treatment; Results of a Retrospective Study
}

\author{
Hend Ahmed El-Hadaad ${ }^{1 *}$, Hanan Ahmed Wahba1 \\ Hayam Fathy Abd-El Hay Ghazy² \\ ${ }^{1}$ Clinical Oncology and Nuclear Medicine department, Faculty of Medicine, \\ Mansoura University, Egypt \\ ${ }^{2}$ Medical Oncology department, Faculty of Medicine, Mansoura University, \\ Egypt
}

Received 30 August 2015; Accepted 15 December 2015

\begin{abstract}
Background: Targeted agents were introduced over past years because of better understanding of oncogenetic mechanisms in metastatic renal cell carcinoma (mRCC). These agents include tyrosine kinase inhibitors (TKIs) such as sorafenib, sunitinib, pazopanib and axitinib. Methods: Review of recorded data from patients' files with mRCC were analysed during the period from August 2008 to December 2014. Those patients were treated by sunitinib as first-line therapy. The data included patients characteristics such as age, sex, ECOG performance status (ECOG PS), number and sites of metastasis and pathological type. Also, we reviewed response to sunitinib therapy, its adverse events and progression-free survival (PFS). Results: This study included 26 patients; median age was 56 years with male predominance $(76.9 \%)$ and $61.5 \%$ of patients were of ECOG PSO. Lymph nodes were the most common site of metastasis (38.5\%) and $46.2 \%$ presented with $\geq 3$ sites of disease. Clear cell pathology was reported in $96.2 \%$. No grade IV adverse events to sunitinib reactions were observed. Thrombocytopenia was the most predominant haematological reaction (46\%) followed by neutropenia (38.6\%), whilst fatigue was the most reported non-haematological one $(50 \%)$ followed by diarrhoea (42.3\%). Partial response (PR) was found in $30.8 \%$ and stable disease (SD) in $46.2 \%$. One-year PFS was $57.7 \%$ with median PFS time of 12 months. Conclusion: This study proved effectiveness and safety of sunitinib as first-line treatment for mRCC. However, this is a retrospective study and relatively small numbers of patients were included, so prospective studies with larger number of patients are needed for further evaluation.
\end{abstract}

Keywords: Sunitinib • Metastasis • Renal Cell Carcinoma • Targeted agents

(c) De Gruyter Open

\section{Introduction}

In adults, renal cell carcinoma (RCC) is the most common type of kidney cancer, responsible for $90-95 \%$ of cases and the predominant pathology is clear cell carcinoma [1]. About $25-30 \%$ of cases are metastatic at the time of diagnosis [2]. As RCC is highly resistant to chemotherapy, immunotherapeutic agents such as interleukin 2 and interferon alpha (IFN- $\alpha$ ) were the only available first-line treatments of metastatic disease [36]. But response rates with thesebagents are low and associated with significant toxicity [7-9].

Targeted agents were introduced over past years because of better understanding of oncogenetic mechanisms in metastatic renal cell carcinoma (mRCC).
These agents include tyrosine kinase inhibitors (TKIs) such as sorafenib, sunitinib, pazopanib and axitinib [1013]. These TKIs targeted the vascular endothelial growth factors receptors (VEGFR) and platelet-derived growth factors receptors (PDGFR) [14, 15].

Tyrosine kinases receptors have an important role in pathogenesis of clear-cell RCC through inactivation of the von Hippel-Lindau (VHL) gene. Inactivation of this gene leads to overexpression of VEGFR and PDGFR resulting in persistent stimulation of the receptors that can promote tumour growth, angiogenesis and metastasis [16].

Sunitinib produced clinical activity in patients previously treated with immunotherapeutic agents in two uncontrolled studies with objective response rates higher 
than that obtained by using immunotherapeutic agents as first-line treatment of metastatic cases [17, 18].

This retrospective study aimed at evaluation of patients with $\mathrm{mRCC}$ treated with sunitinib as first-line treatment in two centres as regard clinico-pathological character, treatment outcome, and survival.

\section{Patients and methods}

Review of recorded data from patient's files with $\mathrm{mRCC}$ attended to Oncology centre, Clinical Oncology and Nuclear Medicine department. Mansoura University hospital were analysed during the period from August 2008 to December 2014. Those patients were treated with sunitinib as first-line therapy.

The data included patients' characteristics such as age, sex, ECOG performance status (ECOG PS), number and sites of metastasis, time from diagnosis to treatment and pathological type. Also, we reviewed the response to sunitinib therapy, its adverse events and progression-free survival (PFS).

Staging procedures included computerised tomography (CT) of chest, abdomen and pelvis. Magnetic resonance imaging (MRI) of the brain, renal biopsy and bone scan were done. Measurable disease was assessed through the Response Evaluation Criteria in Solid Tumours (RECIST) [19].

Sunitinib was administered at a once daily dose of $50 \mathrm{mg}$ orally for four weeks followed by two weeks rest, then repeated as six-week cycles till progression of disease, occurrence of intolerable adverse events or death. PFS was calculated from the date of diagnosis to the date of disease progression.

Adverse events were graded according to the Common Terminology Criteria for adverse events of the National Cancer Institute, v3.0 [20].

Statistical method:

Data were collected and analysed using SPSS version15.0 (Chicago, IL, USA). Data expressed as number and percentile. Kaplan-Meier was used for survival function (PFS).

\section{Results}

This retrospective study included 26 patients; their characteristics are shown in Table 1. Median age was 56 years with male predominance $(76.9 \%)$ and $61.5 \%$ of patients were of ECOG PS 0. Lymph nodes were the most common site of metastasis $(38.5 \%)$ and $46.2 \%$ presented with $\geq 3$ sites of disease. Clear cell pathology was reported in $96.2 \%$.
Table 1. Patients' characteristics.

\begin{tabular}{|c|c|c|}
\hline Character & $\mathbf{N}$ & $\%$ \\
\hline $\begin{array}{l}\text { Age } \\
\text { Median (range) } \\
59 \text { (30-79)years }\end{array}$ & & \\
\hline $\begin{array}{l}\text { Sex } \\
\text { Male } \\
\text { Female }\end{array}$ & $\begin{array}{c}20 \\
6\end{array}$ & $\begin{array}{l}76.9 \\
23.1\end{array}$ \\
\hline $\begin{array}{l}\text { ECOG PS } \\
0 \\
1\end{array}$ & $\begin{array}{l}16 \\
10\end{array}$ & $\begin{array}{l}61.5 \\
38.5\end{array}$ \\
\hline $\begin{array}{l}\text { Site of metastasis } \\
\text { Lung } \\
\text { Liver } \\
\text { Bone } \\
\text { Lymph nodes }\end{array}$ & $\begin{array}{c}6 \\
3 \\
7 \\
10\end{array}$ & $\begin{array}{l}23.1 \\
11.5 \\
26.9 \\
38.5\end{array}$ \\
\hline $\begin{array}{l}\text { Number of disease sites } \\
1 \\
2 \\
\geq 3\end{array}$ & $\begin{array}{c}4 \\
10 \\
12\end{array}$ & $\begin{array}{l}15.3 \\
38.5 \\
46.2\end{array}$ \\
\hline $\begin{array}{l}\text { Pathological type } \\
\text { Clear cell } \\
\text { Non-clear cell }\end{array}$ & $\begin{array}{c}25 \\
1\end{array}$ & $\begin{array}{c}96.2 \\
3.9\end{array}$ \\
\hline $\begin{array}{l}\text { Time from diagnosis to } \\
\text { treatment } \\
<1 \text { year } \\
>1 \text { year }\end{array}$ & $\begin{array}{l}15 \\
11\end{array}$ & $\begin{array}{l}57.7 \\
42.3\end{array}$ \\
\hline
\end{tabular}

Table 2 showed adverse reactions to sunitinib; no grade IV reactions were observed. Thrombocytopenia was the most predominant haematological reaction $(46 \%)$ which is followed by neutropenia (38.6\%), while fatigue was the most reported non-haematological one $(50 \%)$ followed by diarrhoea $(42.3 \%)$, then nausea and vomiting (38.4\%) and hand-foot syndrome (27\%).

Partial response (PR) was found in $30.8 \%$ and stable disease (SD) in 46.2\% (Table 3).

As shown in Fig. 1, one-year PFS was $57.7 \%$ with median PFS time of 12 months $(95 \% \mathrm{Cl}$ : $10.766-$ 13.234).

\section{Discussion}

This retrospective study included group of patients with median age and sex distributions typically for RCC.

Inhibition of angiogenesis is a promising strategy for the treatment of clear-cell RCC [4, 21]. As clear-cell RCC overexpresses many cellular receptors related to angiogenesis, target agents such as sunitinib that affect 
Table 2. Adverse events to sunitinib.

\begin{tabular}{|c|c|c|c|c|c|c|}
\hline \multirow[t]{2}{*}{ Adverse events } & \multicolumn{6}{|c|}{ Grade } \\
\hline & $\mathbf{N}$ & $\%$ & $\mathbf{N}$ & $\%$ & $\mathbf{N}$ & $\%$ \\
\hline Neutropenia & 5 & 19.2 & 3 & 11.5 & 2 & 7.8 \\
\hline Anaemia & 4 & 15.3 & 3 & 11.5 & 1 & 3.9 \\
\hline Thrombocytopenia & 5 & 19.2 & 4 & 15.3 & 3 & 11.5 \\
\hline Fatigue & 5 & 19.2 & 6 & 23.1 & 2 & 7.8 \\
\hline Diarrhoea & 4 & 15.3 & 5 & 19.2 & 2 & 7.8 \\
\hline Hand-foot syndrome & 3 & 11.5 & 3 & 11.5 & 1 & 3.9 \\
\hline Rash & 2 & 7.8 & 2 & 7.8 & 1 & 3.9 \\
\hline Hypothyroidism & 1 & 3.9 & 1 & 3.9 & 0 & 0 \\
\hline Mucositis & 2 & 7.8 & 3 & 11.5 & 0 & 0 \\
\hline Pain in the limb & 2 & 7.8 & 0 & 0 & 0 & 0 \\
\hline Increased total bilirubin & 3 & 11.5 & 1 & 3.9 & 0 & 0 \\
\hline Nausea and vomiting & 4 & 15.3 & 5 & 19.2 & 1 & 3.9 \\
\hline
\end{tabular}

Table 3. Response rate.

\begin{tabular}{l|cc}
\hline Response & N & \% \\
\hline \hline Partial response (PR) & 8 & 30.8 \\
Stable disease (SD) & 12 & 46.2 \\
Progressive disease (PD) & 6 & 23 \\
\hline
\end{tabular}

the activity of angiogenic growth factors show favourable results in the treatment of $\mathrm{mRCC}$. Response rate of our study was $30.8 \%$, comparable to that observed in other trials of sunitinib as first-line and second-line therapies $[17,18]$. Many studies found that these rates are higher than that reported for chemotherapeutic agents or other cytokines [22-25].

Progressive disease was reported in $23 \%$; this primary refractoriness may be explained by different pathogenesis including gene mutations with or without VHL (e.g. BAP1 and SETD2) [26-28].

PFS time in the range of 9.5-14.7 months has been observed in some trials [24, 29, 30], and in our study, it was 12 months.

In a phase II trial, there was no significant difference in safety between continuous or intermittent dosing of sunitinib [31].

Amongst non-haematological adverse events, fatigue was the most common one $(50 \%)$ followed by

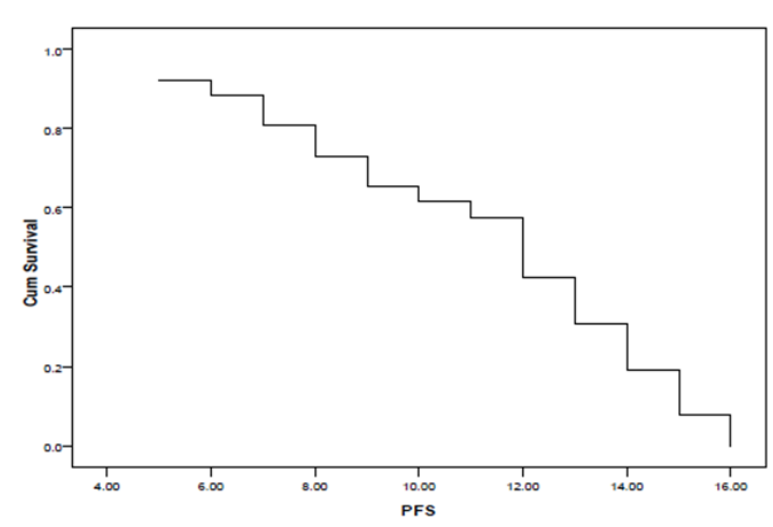

Figure 1. PFS amongst all studied cases.

diarrhoea $(42.3 \%)$, then nausea and vomiting (38.4\%) and hand-foot syndrome $(27 \%)$ in our study. Adverse events of particular concern to patients were fatigue, gastrointestinal toxicity and hand-foot syndrome in other studies [17, 18, 32, 33]. However, in a study conducted by Motzer et al. [24], it was found that grade III or IV fatigue was significantly higher amongst patients received INF- $\alpha$ than those received sunitinib, but they reported higher haematologic adverse events in the sunitinib group; in this study, grade IV events were not observed. 


\section{Conclusion}

This study proved effectiveness and safety of sunitinib as first-line treatment for mRCC. However, this is a retrospective study and relatively small numbers of patients were included, so prospective studies with larger number of patients are needed for further evaluation.

\section{Competing interests}

The authors declare that they have no competing interests.

Informed consent: 'Informed consent was obtained from all individual participants included in the study.'

Ethical approval: 'All procedures performed in studies involving human participants were in accordance with the ethical standards of the institutional and/or national research committee and with the 1964 Helsinki declaration and its later amendments or comparable ethical standards.'

\section{References}

[1] Curti B, Jana BR, Javeed M, Makhoul I, Sachdeva K, Hu W et al. Harris, JE, ed. "Renal Cell Carcinoma". Medscape Reference. WebMD. Retrieved 7 March 2014

[2] Lam JS, Leppert JT, Belldegrun AS, Figlin RA. Novel approaches in the therapy of renal cell carcinoma. World Journal of Urology. 2005; 23:202-12.

[3] McDermott DF, Regan MM, Clark JI, Flaherty LE, Weiss GR, Logan TF et al. Randomized phase III trial of high- dose interleukin-2 versus subcutaneous interleukin-2 and interferon in patients with metastatic renal cell carcinoma. J Clin Oncol. 2005; 23:133-41.

[4] Yang JC, Sherry RM, Steinberg SM, Topalian SL, Schwartzentruber DJ, Hwu P et al. Randomized study of high-dose and low-dose interleukin-2 in patients with metastatic renal cell carcinoma. .J Clin Oncol. 2003; 21:3127-32.

[5] Negrier S, Perol D, Ravaud A, Chevreau C, Bay JO, Delva $\mathrm{R}$ et al. Medroxyprogestrone, interferon alfa$2 a$, interleukin-2 or combination of both cytokines in patients with metastatic renal cell carcinoma. Cancer.2007; 110:2468-77.

[6] Coppin C, Porzsolt F, Awa A, Kumpf J, Coldman A, Wilt T. Immunotherapy for advanced renal cell cancer. Cochrane Database Syst Rev 2005; 2:CD001425.

[7] Fisher RI, Rosenberg SA, Fyfe G. Long- term survival update for high-dose recombinant interleukin-2 in patients with renal cell carcinoma. Cancer J Sci Am.2000; 6: 1:S55-S57.

[8] Motzer RJ, Murphy BA, Bacik J, Schwartz LH, Nanus DM, Mariani $T$ et al. Phase III trial of interferon alfa-2a with or without 13-cis-retinoic acid for patients with advanced renal cell carcinoma. J Clin Oncol.2000; 18:2972-80.

[9] Negrier S1, Escudier B, Lasset C, Douillard JY, Savary J, Chevreau C et al. Recombinant human interleukin-2, recombinant human interferon alfa$2 \mathrm{a}$,or both in metastatic renal cell carcinoma. $\mathrm{N}$ Engl J Med. 1998; 338:1272-8.

[10] Escudier B, Eisen T, Stadler WM, Szczylik C, Oudard S, Siebels M et al. Sorafenib in advanced clear cell renal carcinoma. N Engl J Med. 2007; 365:125-34.

[11] Hutson TE, Bukowski RM, Rini BI, Gore ME, Larkin JM, Figlin RA et al. Efficacy and safety of sunitinib in elderly patients with metastatic renal cell carcinoma.Br J Cancer. 2014; 110:1125-32.

[12] Sternberg CN, Hawkins RE, Wagstaff J, Salman P, Mardiak J, Barrios $\mathrm{CH}$ et al. A randomised, doubleblind phase III study of pazopanib in patients with advanced and/or metastatic renal cell carcinoma: final overall survival results and safety update. Eur J Cancer. 2013; 49:1287-96.

[13] Rini BI, Escudier B, Tomczak P, Kaprin A, Szczylik C, Hutson TE et al. Comparative effectiveness of axitinib versus sorafenib in advanced renal cell carcinoma (AXIS):a randomized phase 3 trial. Lancet. 2011; 378:1931-39.

[14] Abrams TJ, Lee LB, Murray LJ, Pryer NK, Cherrington JM. SU11248 inhibits KIT and plateletderived growth factor receptor beta in preclinical models of human small cell lung cancer. Mol Cancer Ther. 2003; 2:471-8.

[15] Mendel DB, Laird AD, Xin X, Louie SG, Christensen JG, Li G et al. In vivo antitumor activity of SU11248, a novel tyrosine kinase inhibitor targeting vascular endothelial growth factor and platelet-derived growth factor receptors: determination of a pharmacokinetic/pharmacodynamic relationship. Clin Cancer Res. 2003; 9:327-37.

[16] Pantuck AJ, Zeng G, Belldegrun AS, Figlin RA. Pathobiology, prognosis and targeted therapy for renal cell carcinoma: exploiting the hypoxia-induced pathway. Clin Cancer Res. 2003; 9:4641-52. 
[17] Motzer RJ, Michaelson MD, Redman BG, Hudes GR, Wilding G, Figlin RA et al. Activity of SU11248, a multitargeted inhibitor of vascular endothelial growth factor receptor and platelet-derived growth factor receptor in patients with metastatic renal cell carcinoma. J Clin Oncol. 2006; 24:16-24.

[18] Motzer RJ, Rini BI, Bukowski RM, Curti BD, George DJ, Hudes GR et al. Sunitinib in patients with metastatic renal cell carcinoma. JAMA. 2006; 295:2516-24.

[19] Therasse P, Arbuck SG, Eisenhauer EA, Wanders $J$, Kaplan RS, Rubinstein L et al. New guidelines to evaluate the response to treatment in solid tumors. European Organization for Research and Treatment of Cancer, National Cancer Institute of the United States, National Cancer Institute of Canada. J Natl Cancer Inst. 2000; 92:205-16.

[20] Trotti A1, Colevas AD, Setser A, Rusch V, Jaques D, Budach $V$ et al. CTCAE v.3.0: development of a comprehensive grading system for adverse effects of cancer treatment. Semin Radiat Oncol. 2003; 13:176-81.

[21] Escudier B, Szczlik C, Eisen T, Stadler WM, Schwartz B, Shan M et al. Randomized phase III trial of the Raf kinase and VEGFR inhibitor sorafenib (BAY 43-9006) in patients with advanced renal cell carcinoma (RCC). Proc Am Soc Clin Oncol. 2005; 24:380s abstract.

[22] Motzer RJ, Russo P. Systemic therapy for renal cell carcinoma. J Urol. 2000; 163:408-17.

[23] Motzer RJ, Hutson TE, Tomczak P, Michaelson MD, Bukowski RM, Oudard S et al. Overall survival and updated results for sunitinib compared with interferon alfa in patients with metastatic renal cell carcinoma. J Clin Oncol. 2009; 27:3584-90.

[24] Motzer RJ, Hutson TE, Tomczak P, Michaelson MD, Bukowski RM, Rixe $O$ et al. Sunitinib versus interferon alfa in metastatic renal cell carcinoma. $\mathrm{N}$ Engl J Med. 2007; 356:115-24.

[25] Dutcher JP. Recent developments in the treatment of renal cell carcinoma. Ther Adv Urol. 2013; 5:33853.
[26] Porta C, Sabbatini R, Procopio G, Paglino C, Galligioni E, Ortega C. Primary resistance to tyrosine kinase inhibitors in patients with advanced renal cell carcinoma: state-of-the-science. Expert Rev Anticancer Ther. 2012; 12:1571-7.

[27] Joseph RW, Kapur P, Serie DJ, Eckel-Passow JE, Parasramka M, Ho T et al. Loss of BAP1 protein expression is an independent marker of poor prognosis in patients with low risk clear renal cell carcinoma. Cancer. 2014 120:1059-67.

[28] Hakimi AA, Pham CG, Hsieh JJ. A clear picture of renal cell carcinoma. Nat Genet. 2013; 45:849-50.

[29] Motzer RJ, Hutson TE, Cella D, Reeves J, Hawkins $R$, Guo J et al. Pazopanib versus sunitinib in metastatic renal cell carcinoma. $\mathrm{N}$ Engl J Med. 2013; 369:722-31.

[30] Choueiri TK, Garcia JA, Elson P, Khasawneh M, Usman S, Golshayan AR et al. Clinical factors associated with outcome in patients with metastatic clear cell renal carcinoma treated with vascular endothelial growth factor-targeted therapy. Cancer. 2007; 110:543-50.

[31] Motzer RJ, Hutson TE, Olsen MR, Hudes GR, Burke JM, Edenfield WJ et al. Randomised phase II trial of sunitinib on an intermittent versus continuous dosing schedule as first-line therapy for advanced renal cell carcinoma. J Clin Oncol. 2012; 30:13717.

[32] Wong MK, Mohamed AF, Hauber AB, Yang JC, Liu $Z$, Rogerio $\mathrm{J}$ et al. Patients rank toxicity against progression free survival in second-line treatment of advanced renal cell carcinoma. J Med Econ. 2012; 15:1139-48.

[33] Mohamed AF, Hauber AB, Neary MP .Patient benefitrisk preferences for targeted agents in the treatment of renal cell carcinoma. Pharmacoeconomics. 2011; 29:977-88. 